\title{
U nás doma v Evropě a v karanténě
}

\author{
Martin Profant \\ Filosofický ústav Akademie věd ČR, CZ
}

PROFANT, M.: At Home in Europe and in Quarantine

Philosophica Critica, vol. 6, 2020, no. 1, ISSN 1339-8970, pp. 178-188

This paper focuses on a specific strategy of the defence against the COVID pandemic in the countries of the EU. It points out the cultural-historic situation which made it possible for the formation of wide-based consensus with the anti-pandemic measures that strongly limited the social and economic life. It accents the asymmetry of the European solidary decision for the benefit of seniors and seriously ill people. This paper stresses out the European form of the anti-pandemic defence as a highly effective and sympathetic in its values. It states the relative suppression of the distribution of the burden of epidemic according to the social and race key. At the same time, it defines three critical limits of the chosen strategy a) the necessity to suspend the political conflict with the unclear strategy of its future releasing; b) blind spots of spontaneous and institutional solidarity with the possible tragic consequences (the senselessly dead in the retirement houses etc.); c) the conflict of the necessary grounding of the anti-epidemic measures in the institutions of a national state, especially in the solidary insurances and the COVID caused deficits of national budgets contra the cohesion of EU.

Key words: COVID-19 - Spontaneous solidarity - Institutional solidarity - EU - Czech Republic

Přes rozdílný průběh epidemie a různé strategie charakterizuje reakce všech zemí Evropské unie (plus Norska, Švýcarska a neunijních zemí bývalé Jugoslávie) shodná volba: abychom ochránili ty, které COVID-19 zabíjí, tedy lidi na 65 let a lidi chronicky nemocné, ${ }^{1}$ zvolili jsme raději

Na počátku evropské epidemie, tedy na přelomu února a března 2020, zveřejňovaly deníky v jednotlivých evropských zemích údaje o smrtnosti nemoci COVID-19 pocházející ze zprávy Report of the WHO-China Joint Mission on Coronavirus Disease 2019 (COVID-19). Podle ní nedosahovala pravděpodobnost úmrtí při onemocnění COVIDem-19 u lidí mladších padesáti let ani polovinu procenta. Evrop- 
strategii s pustošivými ekonomickými následky, které pravděpodobně ve střednědobém horizontu zasáhnou životy zdravých a aktivních lidí drtivěji, než by je poškodil očekávatelný průběh nemoci. Vzhledem k tomu, že patřím k oné silně ohrožené menšině, mohu bez zápachu sebechvály citovat výrok Sergia Benvenuta: „Cítím něco hrdinského v takové energické obraně těch, kteří už nemají dlouho žít." (Benvenuto 2020)

Zvolili jsme si? Strategie přece vybíraly vlády na radu epidemiologů a lékařù, politická reprezentace je nejvýše následně potvrdila. Jenomže rozhodnutí vlád by $\mathrm{v}$ tomto případě neznamenalo téměř nic bez masivního souhlasu společnosti; tak masivního, že před ním v prvních dvou týdnech zmlkli i ideologičtí fanatici neviditelné ruky volného trhu. Protiepidemická opatření by do značné míry zůstala na papíre, kdyby je naprostá většina z nás dobrovolně a pečlivě nedodržovala. Ovšem, byl zde od počátku ve hře strach o sebe a své nejbližší, ale mnohem více působila odpovědnost vůči druhým. Proto je zcela přiměřené mluvit o konsenzuální volbě.

V České republice jsme se ohledně protiepidemických opatření dobrovolně disciplinovali způsobem, který by si policie a další kasárenské síly státu nikdy nedokázaly vynutit - ke cti policie nutno říct, že většinou pochopila, mile se usmívala a zasahovala jen ve zcela výjimečných př́padech. Našly by se $\mathrm{k}$ té české disciplinaci různá historicko-kulturní zdůvodnění: jsme národ maloměstský, ${ }^{2}$ bezmála čtvrt tisíciletí cepovaný povinnou školní docházkou, která krom elementární gramotnosti podpořila také úctu k vědeckým autoritám, těm lékařským zvláště, a vybudovala odolnou důvěru v odbornou způsobilost vyšší byrokracie; důvěru nezklamatelnou, protože imunizovanou posměšným odstupem. Přes tato česká specifika můžeme spontánní sebedisciplinaci bez rozpaků zobecnit jako celoevropský jev.

V předloženém textu chci naznačit tři limity, které spoluurčují tvar evropského solidárního postoje k současné pandemii.

V prvních dnech epidemie dobrovolnická pomoc zajistila ohroženým seniorům, že nemuseli zbytečně riskovat a vycházet na ulici, ve většině

ský, a zvláště americký průběh epidemie tato čísla trochu korigoval, ale v Evropě platí, že úmrtí na COVID-19 u osoby mladší pětašedesáti let je raritní. K 6. 4. 2020 udávalo pro naši republiku Ministerstvo zdravotnictví ČR [ÚZIS] rozložení úmrtí na COVID-19, které bylo pro lidi pod šedesát stejně příznivé jako to čínské.

2 „Maloměstský národ“ bez ironie a uvědoměle, téměř programově, srov. Karlem Čapkem souhlasně citovanou Benešovu reflexi z roku 1917: „Československý stát bude vzorem moderního státu demokratického: velmi zdatný z hlediska národohospodářského a osvětového, nemaje šlechty a živ jsa $\mathrm{v}$ demokratických tradicích své národní historie, maje více než sdostatek úředníků, techniků, lékařủ a profesorů z lidu vyšlých, může vejíti v život již zítra." (Beneš 1917, 407; Čapek 1919) 
měst a obcí najednou efektivně fungovala bezkonfliktní spolupráce místních samospráv s ad hoc iniciativami.

Dělo se to všude v Evropě, s českými zeměmi se ale nahodile spojil jeden působivý symbol solidarity, domácí šití roušek. Vzpomínám si na televizní reportáž, která nezáměrně poodhrnula nesamozřejmý a nenápadný rozměr tohoto rouškového symbolu. Předváděla jednu z mála opraven šicích strojů, které $v$ Čechách přežily devadesátá léta: zoufale přetížená rodinná dílnička zahlcená př́livem strojů, na kterých se většinou už desetiletí nešilo a ted' si na nich ženy vesměs nejlepšího věku oživovaly dovednosti, které jim kdysi vtloukaly maminky a které spokojeně pozapomněly v době záplavy levné asijské textilní produkce. V Evropě konzumentů se v tom šití připomínal nedávno ještě samozřejmý a dnes již překvapivý industriálně-produkční charakter starého kontinentu. České země tu působily jako vypouklé zrcadlo zvýrazňující jinde méně zřetelné rysy; působily tak nenahodile, domácké šití patřívalo k projevům paradoxní konzumní společnosti nedostatku, nazývané kdysi reálný socialismus; dovednost se šicím strojem tu proto byla rozšířenější než v západní Evropě a předávala se přibližně o jednu generaci déle. Nešlo ale jen o domácky šité roušky. Ve staré průmyslové zemi, ze které třicet let mizí s výjimkou několika segmentů sofistikovanější průmyslová výroba, se aktualizovala industriální tradice a začaly se vyvíjet a v improvizovaných podmínkách vyrábět nejen vynikající ochranné pomůcky, ale také chytré a hospodárné lékařské př́istroje.

Bylo by krásné uvěřit, že procitnutí potenciálu solidarity a vynalézavosti přežije. Krásné a pošetilé. Katastrofa jen na chvíli oslabila imperativy trhu a administrativně-politického systému. Nejpozději po pár týdnech přichází v podobných situacích normalizace, a ta je dnes už vlastně v plném běhu. Symbolický zlom představuje vystoupení ministra průmyslu a obchodu Karla Havlíčka, který nadšeně oznámil jednání s americkou firmou Honeywell o stavbě továrny na výrobu respirátorů provázený de facto monopolizací českých veřejných zakázek (Havlíček 2020); akt poněkud předčasný, české inovativní firmy se mohly ještě příliš opřít o podporu veřejnosti, ale gesto přesto již až př́liš čitelné: trh určí, že se výroba v Česku nevyplácí, leda by ji neprovozovaly slabé české firmy, ale dostatečně mocné nadnárodní korporace; a pokud by mělo neviditelné ruce trhu v tomto předzjednaném určování něco překážet, pak se osvícená státní byrokracie o odstranění podobných překážek servilně postará. Není otázka zda, ale kdy opět začne státní i samosprávná byrokracie na spontánní iniciativy, bez kterých by se protiepidemická opatření v zemi zhroutila, pohlížet navyklým administrativním pohledem, to jest jako na potížisty. 
Utopický přebytek, který v časech otřesů a katastrof vždy doplňuje nástup spontánní solidarity očekáváním trvalejšího odblokování establishmentem zablokovaných pozitivních možností a který - byv vždy zklamán trpkne pravidelně v nostalgii -, kontrastuje na první pohled s racionální střízlivostí, s níž se tato solidarita od počátku slad'ovala s tvrdým administrativním restriktem každodenního života. Odpovídala tomu přátelská otevřenost a láska k bližním a i těm nejbližším, jež se osvědčovala tím, že jsme si ty bližní drželi doslova na distanc - a to na distanc úředně štemplovaný, vyhlašovaný s variacemi několika centimetrů na ranních tiskovkách Ministerstva zdravotnictví ČR. To je ta část obrazu, na kterou svítily sentimentální reflektory masmediální podpory protiepidemických opatření. Trochu ve stínu zůstal ale poklid, s nímž jsme přijímali a napravovali zmatené předpisy požadující např. nošení roušek v době, kdy jich nebylo dost ani pro nemocnice, nebo cestovatelskou karanténu, při níž se př́kazce nijak nestaral o to, co budou lidi, kteří striktně nesměli vystrčit nos z bytu, jíst. Prostě jsme se o to bez brblání postarali sami.

Důvěřovali jsme vládě a úřadům, že dělají to nejlepší, co umí. Nikoliv už, že dělají to nejlepší. Respektujíce moudrost přísloví „Když vůz jede z kopce, voly nepřepřahej!", neopomněli jsme většinou poválet ta tažná hovádka se shovívavou zlomyslností po jazyku. Přesto se situace v českých zemích přiblížila weberovské vůdcovské demokracii. Lid přijal a respektoval, kdo má ve stavu nouze mluvit a přikazovat, sám držel pusu a očekával to i od druhých. A to dokonce i lid médii pracující. Našel-li se opoziční politik natolik beztaktní, že nepochopil, a takových bylo málo, mluvil k hluchým uším a tvářím s povytaženým obočím. A když se ukázalo, že svěřenou důvěru nezvládají sami ministři a začínají se mezi sebou hašteřit, stal se hrdinou dne profesor Roman Prymula, epidemiolog s téměř absolutním nedostatkem porozumění pro politické záležitosti. Nezdá se ovšem, že by čeští vládní politici znali pointu weberovské anekdoty:

„V demokracii lid volí svého vůdce, kterému důvěřuje. Ten, koho si zvolili, pak řekne: ,Ted' držte pusu a poslouchejte.' Lid ani strany mu už do toho nesmějí mluvit. [...] Později může lid nad vůdcem vynést soud: pokud se dopustil chyb - na šibenici s ním!“ (Weber $1989,665)^{3}$

Obejde se to zřejmě bez šibenic a snad i kriminálů, ale všechna drobná i větší selhání, pro které měl lid ještě včera solidární pochopení, představují dluh s lichvářským úrokem k tíži vládním stranám. Od př́liš křiklavě

3 Citováno podle půvabného českého překladu v (Skovajsa 2019, 129). 
předražených zakázek až po premiéra, který mlčí o zavřených školách a stará se o otevření psích salonů.

Pokud mohu soudit, podobně byl krátkodobě suspendován střet politických stran ve prospěch „vůdcovské demokracie“ ve většině zemí EU. Někde bez českého švejkovského podtónu, jinde se zatatými zuby. Ve zvláštní situaci se ocitlo Slovensko. Vstoupilo do pandemické doby těsně po zlomových volbách, jež přepsaly slovenské politické spektrum, a proto efekt dočasné akceptace funkční autority vlády a úřadů působil zřetelně slaběji než v druhé zemi bývalého Československa a zůstala působivá masivní roztržka ve slovenské společnosti. Přesto byla slovenská racionální stř́izlivost dost silná, aby země nepropadla do malé skupinky masových západních demokracií, ve kterých ti vládnoucí museli bud' sáhnout k diktátorským opatřením (Mad’arsko), nebo ofenzivně zneužívají výjimečnou situaci k útokům na neumlčitelnou opozici (Polsko); a již vůbec se nepropadla tam, kde Trump nebo Johnson nebyli ochotni přijmout ani na okamžik roli státníků, a tudíž i dočasné suspendování stř̌etu politických stran.

\section{II.}

V evropské strategii boje s epidemií mohla spontánní solidarita působit tak efektivně, protože se opírala o systémy institucionální solidarity. Všeobecné zdravotní a nemocenské pojištění mají ve velké části Evropy staletou tradici, ale tam, kde získaly masový charakter až po druhé světové válce, zajistily rychlý nástup masivního testování a okamžitého zachycení většiny vážných případů. Zajistily ale ještě jednu věc - napříč sociální stratifikací společnosti máme v Evropě podchycené a většinou kompenzované nemoci kardiovaskulárního systému a diabetes, tedy choroby zvyšující riziko smrtelného průběhu nemoci COVID-19. Většina evropských zemí měla, opět díky tradici veřejného zdravotnictví, solidní kapacitu ke zvládnutí epidemie, včetně lůžek intenzivní péče. ${ }^{4}$

USA bohužel poskytly až př́liš přesvědčivé srovnání dokládající efektivitu evropského solidárního zdravotního pojištění. Právě jeho absenci musíme zřejmě připsat tamější navýšení smrtnosti nemoci COVID-19 v mladších věkových kohortách a statisticky zaznamenatelnou souvislost vážných a smrtelných př́ípadů nemoci v těchto kohortách s příslušností

Ta sice nestačila $\mathrm{v}$ nejpostiženějších zemích, ale i tam byla vysoko nad světovým průměrem. Pro celounijní srovnání kolují údaje ze studie vypracované A. Rhodesem s kolegy (Rhodes et al. 2012). Podle této studie měly před osmi lety Belgie, Itálie a Francie více lůžek intenzivní péče na 100000 obyvatel než byl evropský průměr (Belgie 15, 9; Itálie 12, 5; Francie 11, 6 stejně jako ČR; EU 11, 5). Pro srovnání - podle dat aktualizovaných v březnu 2020 ÚSIZ to v ČR činí 52, 4 IP lůžek (Černý 2020). 
k nižším př́ímovým skupinám a odvozeně s askriptivní kategorií rasy. Nejedná se přitom jen o zdravotní a nemocenské pojištění, oproti Evropě působil v USA mnohem výrazněji fenomén, který se nejvýrazněji projevil v chudých zemích globálního Jihu. Evropští chudí mohli dodržovat nařízená protiepidemická opatření včetně razantního omezení pohybu, aniž by jim hrozil okamžitý hmotný nedostatek nebo v těch nejchudších zemích přímo smrt hlady.

Evropské systémy solidárních pojištění a záchranných sociálních sítí, státem iniciovaná územní struktura nemocnic a zdravotnických zařízení, relativně masivní a obvykle značně centralizovaný administrativní hygienický systém jednotlivých národních států, tato typicky evropská kombinace působí dokonce i při zohlednění nejpostiženějších evropských států (Itálie, Španělska a Francie) jako nejvhodnější forma organizace umožňující minimalizovat ničivé dopady epidemií.

Jenomže nejen spontánní, ale i institucionální solidarita přestává fungovat za horizontem našeho pohledu a zapomínáme na ni vůči těm, kdo se neozývají či jejich hlas není slyšet. Jestliže jsem na počátku zdůraznil evropské odhodlání chránit ty, kteří už nebudou dlouho žít, pak je třeba dodat, že selhalo na místě nejbolavějším. Zprávy o nakažených a občas také personálem v panice opuštěných domovech a dalších zařízeních pro seniory se začaly ozývat ze všech koutů Evropy včetně Německa, které bylo po materiální stránce připraveno na epidemii zřejmě nejlépe. $V$ běžném životě se na tyto čekárny na smrt snažíme zapomenout, děsí nás jako naše pravděpodobná budoucnost a děsí nás, protože vlastně v přítomnosti neumíme pomoci. Chybí peníze, aby v těchto zařízeních bylo dost personálu; a chybí i lidé, kteř́ by se těmi penězi mohli zaplatit - většina z nás by v podobně depresivním prostředí prostě nedokázala pracovat. Místo prevence se proto jen truchlilo. V České republice se ministrům podařilo do toho truchlení vnést prvek grotesky, když místo roušek, rukavic a digitálních teploměrů poslali do domovů seniorů manuál, jak je používat, jinak jsme se ale z obecného trendu smrtícího zapomínání nevymkli. ${ }^{5}$

Jedno zlo, které dost často provází epidemie, COVID-19 do Čech a na Moravu nepřinesl. Nedošlo ke stigmatizaci některé z menšin jako nebezpečného nositele nákazy, ve veřejném prostoru zašla $v$ tomto ohledu

Otevřený dopis Daniely Luskové z 28. 3. 2020 ministrovi zdravotnictví a ministryni práce a sociálních věcí, který paní ředitelka domova seniorů U Biřičky v Hradci Králové nadepsala pregnantně: „Nedělejte $\mathrm{z}$ nás blbečky!“, představoval asi první veřejnou kritiku české vlády od počátku epidemie, která získala širokou souhlasnou odezvu. A nic nepomohlo, když si ministr kultury vzhledem k nadbytku verzálek a vykřičníků v textu dopisu veřejně zaspekuloval o hysterické osobnosti pisatelky. Viz Lusková (2020). 
zřejmě nejdál reportáž ČT, která spíše z hlouposti než zlého záměru překřtila COVID-19 na „čínskou nemoc“.6 Obecně xenofobové a rasisti v prvním měsíci epidemie spíše mlčeli, a pokud se strach z nemoci lokálně přetavoval do nenávisti, zaměřovala se zvláště $\mathrm{v}$ menších sídlech vůči lidem v cestovatelské karanténě a obyvatelům hlavního města. Podobné to bylo ve většině evropských zemí. Na Slovensku se ovšem odehrál podivný př́iběh s romskými osadami, který sice po právu provokoval k interpretaci jako projev rasismu, osobně považuji za přiměřenější uvažovat o něm v prvé řadě jako výše zmíněném zapomínání za horizontem našeho pohledu.

Ono je od čeho odvracet oči: masivní nezaměstnanost - přibližně dvacet tři tisíc lidí bez př́ístupu k pitné vodě; napojení na kanalizaci, septik nebo čistička jen jako nepravděpodobná výjimka; ${ }^{7}$ úroveň dostupného vzdělání, nad kterým by se zhrozili už za Marie Terezie; zabijácké drogy; lichva - výčet sociálně patologických jevů pouze př́kladný a rozhodně neúplný. Zapouzdřený svět beznaděje.

Vzhledem ke katastrofickým hygienickým poměrům představují romské osady objektivně vysoké epidemické riziko a slovenskou vládu ctí, že zareagovala při prvních zprávách o navrátilcích z Británie. Testování v osadách byl potřebný a vůči obyvatelům osad odpovědný krok, dokonce i podivný nápad svěřit právě toto testování armádě nebyl zřejmě projev zlé vůle. Pak ale přišlo neuvěřitelné provedení: plošná karanténa osad, nikde neodůvodněná počtem nakažených, která uzavřela přes šest tisíc lidí na území s nedostatkem pitné vody, bez obchodů se základními potravinami a ochrannými pomůckami. Kdyby chtěla slovenská vláda vytvořit co nejlepší podmínky pro šíření nemoci COVID-19 v osadách, sotva by mohla postupovat jinak. Bez pomoci NNO a aktivistů hrozily navíc tragické důsledky logistického selhání. Doufejme, že do rodu novinářských kachen patří vyprávění o starostovi, který se $\mathrm{v}$ době, kdy v osadě chyběly léky, staral jen o to, aby se do ní nedostal alkohol (Večera 2020). Kumulovalo se napětí, které nakonec vyvrcholilo v obludném a zcela lživém útoku premiéra Matoviče na neziskové organizace. Dehumanizace obyvatel osad na pouhé nositele nebezpečí má zatím poslední nehezký akt. 27. 4. měl policista zbít pět malých dětí z osady v Krompachách, které se pohybovaly na okraji karanténní zóny (Romea [ryz.] 2020). Stalo se to v době, kdy už bylo oznámeno, že důvody uzavření osady pominuly a bude v nejbližší

6 Mai Nguyenová popisuje podezřívavost a ostražitost české veřejnosti vůči Asiatům, který pocitovali Vietnamci v ČR na počátku epidemie (Nguyenová, 2020). Pokud je mi známo, tato podezřívavost rychle odezněla a nikde nepřerostla do xenofobní agrese.

7 K hygienické katastrofě osad viz Atlas romských komunit (2019). 
době otevřena (osada byla otevřena 1. 5.) To, co začalo jako administrativní hloupost a populistická bezohlednost, tak přerostlo do otevřeného sporu, který přinejmenším zanechá další jizvu překážející integraci.

\section{III.}

Trvalo jen dva krátké březnové týdny a státy unie oddělily téměř nepropustné hranice. Evropská komise se sice na chvíli pokusila trendu vzdorovat, ale jaksi nevýrazně a rezignovaně. A ovšem zbytečně, vždyt' ty hranice vytvořila právě výše popsaná efektivní organizace zdravotnictví a administrativních prostředků, která začala potlačovat epidemii. Tato organizace se vždy plně váže na příslušný národní stát. A také ona tak významná spontánní solidarita rostla z národně-občanského principu, nemohla dost dobře jinak, české nebo slovenské sympatie s těžce zkoušenými latinskými zeměmi nebylo jak proměnit v činy. Státy Evropské unie přijímaly rozhodnutí o uzavření svých hranic s rozpaky, donuceny mocí faktického. Tu a tam sice někdo vyslovil obavu ze šovinistického populismu, který uzavírá hranice, aby demonstroval své odhodlání chránit „naše“ před „cizáky“. Ale zdá se, že se podobné výroky mluvčím přihodily spíše jako podmíněný ideologický reflex; v souvislosti se zeměmi EU, se smutnou výjimkou Madarska a Polska, působila tato obava nepř́padně, téměř směšně. Teprve Trumpovo populisticko-šovinistické hledání viníka toho, proč USA v boji s epidemií tak selhaly, a jeho výčet nepřátel: Číny, nezodpovědných Evropanů a nakonec „pročínské“ Světové zdravotnické organizace, připomněly, jak nadmíru nebezpečná zůstává figura vytváření nepřítele.

Většina Evropanů považovala pozastavení volného přeshraničního pohybu osob za dobře odůvodněnou nezbytnost a nijak nepochybovala o jeho dočasnosti. Přes racionalitu rozhodnutí a jeho konsenzuální uznání je ovšem uzavření hranic vše, jen ne nevinné. V malé České republice postihlo zavření hranic přinejmenším desítky tisíc lidí - pendlerů dojíždějících za prací přes hranice. Nemáme ani tušení, o kolik lidí se jednalo v celé EU. Jde přitom jen o špičku ledovce; Evropu dnes pokrývá hustá sít nejrůznějších firem, ve kterých jednotlivci nacházejí obživu a odbornou realizaci, a tato sít' se nedokáže z měsíce na měsíc přizpůsobit realitě tvrdých státních hranic. Totéž se týká zásobování a služeb.

Tak jako u napadených jedinců posiluje nebezpečnost koronaviru předchozí chronické onemocnění, v případě Evropské unie dodává ataku pandemie smrtící potenciál chronicky neřešený problém prohlubování integrace. A právě jako přesvědčený stoupenec EU musím přiznat, že se jedná o smrtící kombinaci. 
Až přejde epidemie, zůstane nejistota. Všichni budeme vědět, že se kdykoli může objevit nový vir a hranice se opět uzavřou. Tato nejistota nebude mimo jiné dobrá pro byznys, a jen proto můžeme považovat za realistickou šanci, že by vznikla dostatečně silná evropská hygienická služba, unijní hmotné zásoby a krizový epidemický fond, snad i dohoda o vzájemné kooperaci při epidemii v některých zemích EU.

Mnohem beznadějněji vypadá jiný malér, který epidemie nemoci COVID-19 aktualizovala. Itálii, Španělsko a Francii postihla epidemii mimořádně ničivě a shodou okolností se zároveň jedná o tři v rámci EU mimořádně zadlužené země. Rozhodně nelze očekávat, že by v prríštích letech mohly plnit maastrichtská kritéria. Itálie proto zcela racionálně obnovila diskusi o eurobondech, unijních dluhopisech. Jedná se o tržně zcela konformní řešení, které by dalo zemím Jihu možnost financovat svůj dluh za příznivějších podmínek, aniž by jim přitom poskytlo prostor pro nějaké nezodpovědné plýtvání. Itálie ovšem narazila na tvrdé odmítnutí. Uvažuje se sice o Marshallově plánu 2, ale podmínky, které se pro jeho využití zatím rýsují, by zahnaly Itálii pod podobnou kuratelu, pod kterou se před deseti lety ocitlo Řecko.

Výčet trhlin v EU, které epidemie COVID-19 nemilosrdně nasvítila, by mohl pokračovat ještě dlouho bod za bodem. Působil by stále beznadějněji. Vnucovala by se otázka: Proč by EU v době strmého propadu světového hospodářství měla dokázat to, co nevyřešila $v$ těch nejoptimálnějších podmínkách? Kupodivu, ta otázka vede k poměrně optimistické odpovědi: Protože ta řešení se mohla v optimálních podmínkách odkládat.

\section{Místo závěru}

Archivní fotografie z posledního říjnového týdne roku 1918 ukazují pražské ulice plné manifestujících lidí; a pokud nemanifestují, alespoň se shlukují v živě debatujících skupinách. Kdo by byl doma, když padá monarchie a zakládá se nový stát? Na fotografiích ovšem nevidíme, že právě v tom týdnu v Praze kulminovala ničivá vlna španělské chřipky, které od 12. září do konce ř́ína podlehlo 893 lidí (Rozsypal 2018). Nevzpomínám si, že by nějaký pamětník včetně těch, u kterých by poznámka o morovém pozadí vzniku Československa tuze „štymovala“ s jejich zatrpklým nesmířením se s novým státem, nebo historická studie tu podivnou koincidenci zmiňovali. Nevzpomínám si, ale prověřit to nemohu, protože knihovny jsou zavřené. Místo dokumentované úvahy o tom, jak se propastně změnila v průběhu sta let česká a evropská senzibilita vůči hrozbě nákazy, nabízím jen kontrastní momentku. 
Totéž se týká většiny témat otevřených v textu. Nemohou být než první reflexe, záznam pro budoucí promýšlení. Děje nejsou ani relativně uzavřené a chybí odstup, stále člověku leží onen pověstný pythagorejský vůl na jazyku, tedy mlčení vyplývající z loajality k těm, kteří nesou odpovědnost rozhodování v krizi.

\section{Literatura}

Atlas romských komunit (2019): Web. 30. 4. 2020. <https://www.minv.sk/?atlasromskych-komunit-2019>.

BENEŠ, E. (1917): Quelques vérités simples sur la fédéralisation de l’Autriche-Hongrie. In: La Nation Tchèque, Revue bimensuelle, 3 (12) [1. 12. 1917].

BENVENUTO, S. (2020): Forget about Agamben. In: European Journal of Psychoanalysis [Coronavirus and philosophers]. Web. 30. 4. 2020. <https:// www.journal-psychoanalysis.eu/coronavirus-and-philosophers/>.

ČAPEK, K. (1919): Jeden rok, Národní listy 23. 2. 1919.

ČERNÝ, V. (2020): Dostupnost intenzivní péče pro hospitalizované pacienty s COVID-19, ÚZIS. Web. 30. 4. 2020. <https://koronavirus.mzcr.cz/wp-content/ uploads/2020/03/Dostupnost-intenzivn\%C3\%AD-p\%C3\%A9\%C4\%8Depro-hospitalizovan\%C3\%A9-pacienty-s-COVID-19.pdf>.

HAVLÍČEK, K. (2020): V Olomouci se mají vyrábět miliony respirátorů měsíčně, Česko bude soběstačné, tvrdí Havlíček. 8. 4. 2020. Web. 30. 4. 2020. <https:// www.novinky.cz/koronavirus/clanek/v-olomouci-se-maji-vyrabet-milionyrespiratoru-mesicne-cesko-bude-sobestacne-tvrdi-havlicek-40319865>.

LUSKOVÁ, D. (2020): Otevřený dopis ministrovi zdravotnictví a ministryni práce a sociálních věcí. 29. 3. 2020. Web. 30. 4. 2020. <https://www.kralovedvorsko. cz/sluzby-obcanum/socialni-sluzby/nedelejte-z-nas-blbecky-otevreny-dopisministru-zdravotnictvi-a-ministryni-prace-a-socialnich-veci.html>.

NGUYENOVÁ, M. (2020): Česká vietnamská komunita v časech koronaviru: pohled částečně zevnitř. In: Deník Referendum 5. 4. 2020. Web. 30. 4. 2020. <https://denikreferendum.cz/clanek/31015-ceska-vietnamska-komunita-vcasech-koronaviru-pohled-castecne-zevnitr>.

Report of the WHO-China Joint Mission on Coronavirus Disease 2019 (COVID-19). Web. 30. 4. 2020. <https://www.who.int/docs/default-source/coronaviruse/ who-china-joint-mission-on-covid-19-final-report.pdf>.

RHODES, A. - FERDINANDE, P. - FLAATTEN, H. - GUIDET, B. - METNITZ, P. G. MORENO, R. P. (2012): The variability of critical care bed numbers in Europe, In: Intensive Care Med, 38, 1647 - 1653. Web. 30. 4. 2020. <https://doi. org/10.1007/s00134-012-2627-8>.

Romea [ryz.] (2020): Polláka Bučková podali trestníoznámenív souvislostise zbitím romských dětí v Krompachách. In: Romea 1. 5. 2020. Web. 2. 5. 2020. <http:// www.romea.cz/cz/zpravodajstvi/zahranicni/pollak-a-buckova-podalitrestni-oznameni-v-souvislosti-se-zbitim-romskych-deti-v-krompachach>.

ROZSYPAL, H. (2018): Před sto lety dorazila do Prahy epidemie španělské chřipky. In: Infekce.cz. Web. 30. 4. 2020. <https://www.infekce.cz/zprava18-30.htm>. 
SKOVAJSA, M. (2019): „Vůdcovská demokracie“ podle Maxe Webera a její ohlasy v české sociologii. In: Hanyš, M. - Pavlíček, T. W. (eds.): Dějiny, smysl a modernita. K 75. narozeninám Miloše Havelky. Praha: Masarykův ústav a Archiv AV ČR FHS UK.

VEČERA, P. (2020): Nakažené romské osady hlídá armáda. In: Expres. cz 22. 4. 2020. Web. 30. 4. 2020. <https://www.expres.cz/zpravy/karantenakoronavirus-coronavirus-covid-19-priznaky-romske-osady-slovenskoarmada.A200422_130529_dx-zpravy_peve>.

WEBER, M. (1989): Max Weber. Ein Lebensbild. München - Zürich: Piper.

PhDr. Martin Profant, PhD.

Centrum globálních studií

Filosofický ústav Akademie věd ČR

Jilská 1, 11000 Praha 1

Česká republika

profant@flu.cas.cz 